Article

\title{
Model of Business Relations in Spa Tourism Enterprises and Their Business Environment
}

\author{
Adam R. Szromek $\mathbb{D}$ \\ Department of Organization and Management, Institute of Economy and Informatics, Silesian University of \\ Technology, Akademicka 2A, 44-100 Gliwice, Poland; innowator@o2.pl; Tel.: +48-32-277-7336
}

Received: 29 May 2020; Accepted: 15 June 2020; Published: 17 June 2020

\begin{abstract}
Sustainable tourism, carried out on spa tourism enterprises, is a key issue that requires the combination of the implementation of economic goals of business activity and, at the same time, the limitation of negative influences on the tourist areas, which are valuable from the point of nature. The main objective of this article and, at the same time, the objective of theoretical-cognitive and empirical research, is to find links and mutual relations between the entities carrying out tourist and therapeutic activity in health resorts in a model approach, taking into account sustainable tourism elements. The implementation of the goal will be carried out on the basis of empirical studies, covering business models of 17 of the largest health resorts in Poland. The article describes relations occurring in the health resort environment and defines a model of relations between health resort enterprises and other entities functioning within this sector. The network approach of the studied issue is analyzed from the point of view of relations found in the complementary cooperation of entities, among which one is ready to implement the benefit and others express their need for the said benefit and are willing to be its recipients. The network relation of the second type, where the entities combine their forces to meet a common goal, is presented in the form of exemplification of the health resort enterprise network in the Polish market.
\end{abstract}

Keywords: sustainability; business model; spa tourism; business environment

\section{Introduction}

Sustainable tourism, carried out in health resort areas, is a key research issue, having, at the same time, important practical effects. The necessity of combining the economic objectives of business activity and limiting its negative influence on health resort resources seems to be very difficult, if not contradictory. The complexity of the issue is further enhanced by the necessity to implement these objectives within the whole sector or its part. While the attempt to balance the activity within its own business model is possible to capture and regulate, the cooperation between particular entities of this market within the same proecological or cultural objectives can be more difficult [1]. However, this requires the analysis of mutual relations between a health resort enterprise and other entities functioning on the market. The contemporary approach to mutual relations to achieve synergy [2] cannot be based solely on quantitative criteria, especially in the area of price, but also on qualitative criteria, especially in terms of sustainable economic and social goals [1].

The main objective of this article and, at the same time, the objective of theoretical-cognitive and empirical research, is to find links and mutual relations between the entities carrying out tourist and therapeutic activity in health resorts in a model approach, taking into account sustainable tourism elements. Identification of relationships between dependent entities operating on the spa tourism market, as part of one business model or linked business models, will help managers of spa companies to look at the structure of market connections from a broader perspective. This approach to mutual business relations will enable individualized optimization of economic activities aimed at finding 
sustainable solutions, in terms of costs and material savings, shortening delivery times, and changing the chain of relationships.

The general objective defined above is divided into two more specific cognitive objectives. The first specific objective is of theoretical and cognitive nature and is directed towards the identification of functioning mechanisms of health resort enterprises. The second objective (of empirical type) concerns the identification of the relationship between the health resort enterprises and their environment. The implementation of this objective requires its own research that covers the analysis of business models of health resort enterprises. After obtaining the research results, the four-factor approach to design space analysis [3] is used, and the conclusions are presented.

The network approach of the studied issue is analyzed from the point of view of relations found in the complementary cooperation of entities, among which one is ready to implement a benefit and others express their need for the said benefit and are willing to be its recipients. The network relation of the second type [4], where the entities combine their forces to meet a common goal, is presented in the form of exemplification of the health resort enterprise network in the Polish market.

\section{Literature Review}

The Global Sustainable Tourism Council (GSTC) [5] has developed criteria that are arranged in four pillars: sustainable management, socioeconomic impacts, cultural impacts, and environmental impacts (including consumption of resources, reducing pollution, and conserving biodiversity and landscapes). When discussing sustainable management, it was emphasized how important the modeling of business is, which fosters the protection of culture and the natural environment. In this aspect, the spa areas are very sensitive, meaning areas valuable from the point of nature, with health resources and health properties of the climate, where the infrastructure allowing for the implementation of tourist and therapeutic functions is located. Mutual relations between entities of the spa sector should be based on the responsibility to protect natural resources and local culture. Otherwise, the changes caused by overtourism can degrade the spa area and limit its tourist and therapeutic functions. Therefore, what is crucial is the proper formulation of relations between the health resort enterprise and its environment (suppliers, recipients, spa communes, partners, competition), taking into account practices protecting the health resort areas.

The health resort is a specific tourist and therapeutic entity, with various forms and tasks implemented in the health resorts for patients and spa tourists. This is not an easy area of activities to be defined, both by theoreticians and by practitioners, as the enterprise functioning in such an area implements both tasks, falling within the scope of tourism (within the private sector) and public health (within the public sector). The structure of Polish health resorts, carried out in the form of health resort facilities, covers such types of constituent entities as spas, spa hospitals (with associated catering facilities), as well as spa centers for children, spa clinics, and natural therapy centers rendering medical services [6]. However, apart from the spa enterprises in the health sector, there are also other dependent social and economic entities for which the enterprise can be a service provider, a recipient of medical raw materials, a beneficiary of contracts, and even the main provider of health policies. The importance and extensiveness of the roles in the specific relations require the standardization of the structure of links between these entities in the form of a business relations model, where the starting point is the health resort business model.

\subsection{Responsiveness of Enterprise to the Change of Business Environment}

Business modeling is a crucial organizational process for every enterprise. Its result is, in general, the model describing processes taking place in the business activity, as well as their link with the environment influencing the enterprise. Therefore, a business model is the characteristics of the described business [7] or a description of relations between components in an organization that result in the creation of value for the organization [8]. A business model is also a visual depiction of an organization's functioning logic, its elements, or ventures in the form of appropriately named, 
interlinked elements of a template that-once populated with content-ensure logical understanding of the process of functioning, survival, and development of an organization [9]. However, another definition of a business model indicates that it is a conceptual tool, containing a set of elements and their relations with defined objectives, allowing us to expose the company's business logic. At the same time, it is a description of values that the enterprise is able to provide to market segments of the organization, along with its network relations with partners, to create value [10-12]. The idea of a business model as a tool is also promoted by D. Teece [13,14], who perceives it as a tool describing the design or architecture of creation, supply, or value-capturing mechanisms. S. Prendeville and N. Bocken [15] describe the business model as a conceptual tool, describing the activities that refer to business transactions between customers, partners, and suppliers, as well as the organization and their participation in the development and capturing of value.

The creators of the CANVAS business model structure, A. Osterwalder and Y. Pigneur [3], proposed a complex approach to create business models. They named six techniques of designing business models that can be treated as managerial tools. At the same time, they revealed six perspectives of creating models: (1) customer's inspiration, (2) creation of ideas, (3) visual thinking, (4) creation of prototypes, (5) storytelling, and (6) scenarios. As a consequence, a nine-element template of a business model named CANVAS was designed. These nine interconnected elements influencing one another are customer segments, value proposals, distribution channels, customer relations, revenue streams, key resources, key activities, key partners, and costs structure. Some of them strongly depend on the environment, which significantly influences the shape of such elements as key customer relations and partner relations in the environment and recipients' segments or distribution channels and key resources, as well as key activities.

The developments of the Board of Innovation [16], which has presented multiple innovative solutions and examples of business models for numerous industries, can be very helpful. The Board of Innovation explains that the innovation programs can be defined as the activity that influences and introduces innovations to a company's strategy. One of the dimensions is the scope of innovation influence intensity, and the second is the opportunities that the organization has. Therefore, the Board of Innovation has developed a modern manner of presenting mutual interactions taking place between the enterprise and its environment, as well as other participants of the same sector. The presentation of these relations can foster the correctness of formulating a business model of an enterprise functioning in a turbulent environment.

It seems that this is a very important remark, as, so far, the research has been more focused on the internal relations of the enterprise and rarely on external relations. It must be noted, however, that the enterprise is functioning in a specific environment that influences the enterprise and changes due to the business activity of the enterprises functioning in them. K. Obłój [17] pays attention to the fact that strategic decision-making requires strategic analysis of the environment and the analysis of the organization. The analysis of the environment and understanding of the present challenges, opportunities, and threats requires us to look at the environment of the company and then carry out a more indepth analysis of the industry and strategic group within which the company competes. Intrasectoral competitiveness of competition, complemented with the influence of suppliers, recipients, substitutes, and new market participants (new products), allows us to start a discussion on the competitiveness of the enterprise. However, such an analysis does not provide a full scope of information on the dynamics of the changes taking place. Meanwhile, establishing a business model requires such analysis not only in the context of one enterprise but also the whole sector within which the enterprise is functioning.

It must be noted that the literature presents such intrasectoral relations influencing the shape of the enterprise business model. According to B. Nogalski [18], it is the sector that forces the manner of carrying out business activity on the enterprise. It applies to the configuration of resources, activities, as well as offered products and services that ensure the creation of value for customers and the generation of profit for enterprise owners. The redefinition of a business model (also defined as strategic 
regeneration) is a process that should ensure that the enterprise matches the external conditions, thanks to reorganization, diversification, divestment, change of technology or business activity, and/or re-engineering of operational processes or product portfolios. According to M. Porter [19], the sector is a part of industry grouping enterprises manufacturing products or providing services of similar purpose (substitutes) and selling them on the same geographical market. Meanwhile, K. Obłój [17] emphasized the complexity and dynamics of the environment, understood not only from the perspective of market and industry but also as a complex system of numerous trends, events, and markets creating the context for a company's function (meaning environment). The dynamics of changes in an enterprise's environment dictate the pace of the changes in the enterprise.

A. Osterwalder and Y. Pigneur [3] have suggested approaching the environment analysis as a design space to see the context where the new or changed business model should function. Therefore, they proposed to base the environment analysis on four factors, that is on (1) forces influencing the market, (2) forces present in the industry, (3) the most important trends, and (4) macroeconomic forces. The forces influencing the market are characterized by way of market segments, needs and expectations, market problems, costs of change, and by way of revenue attractiveness. The forces influencing the industry are suppliers and other elements of the value chain, stakeholders, present and prospective competitors, and substitution products and services. The key trends are characterized by way of technological, regulatory, social, and cultural trends, as well as social and economic trends. The fourth category, meaning macroeconomic forces, is analyzed through global market conditions, capital markets, economic infrastructure, as well as goods and other resources.

The approach proposed by A. Osterwalder and Y. Pigneur is similar to the concept of the integrated model (process) of management that treats the enterprise as a whole and not as a set of various functions and presents a new manner of organizing its future, with the use of the term of a system, as well as system properties and relations [20]. It is not a common approach, and due to the type of managers' reactivity, four models of proceeding [18] towards the new situation of the enterprise can be distinguished. The first model is the so-called passive enterprise, where no reaction to the occurring situation can be observed. It results from both the lack of knowledge of the changes taking place, as well as from the lack of faith in their stability, and the expectation that the situation will change back. The consequences of such a type of activity are the loss of competitiveness, greater distance from the position of leader, or even bankruptcy.

The second model is the so-called reactive enterprise, where the reaction to the changes taking place in the environment can be observed, but these are often delayed reactions resulting from a specific forced change (such as a change of law or market changes). The third type is the so-called proactive enterprise, where the future is predicted, and even trend forecasts are prepared, meaning its reaction to change is the fastest. However, all types of enterprises, be it passive, reactive, or proactive, depend on changes in the environment. The fourth type differs from the previous weak reactions to the environment as it independently shapes its environment with the use of its own resources. These are active enterprises, which are the leaders when it comes to market participation, political links, or innovation [18].

\subsection{Interorganizational Relations}

A modern creation of mutual relations between enterprises functioning on a specific market is often based on building an interorganizational network. H. Håkansson and D. Ford [21] claimed that the terms relation and network has become inseparable in the business dialect between enterprise managers. C.M. Hall [22] defines network as an interorganizational cooperation agreement. In subsequent works, he cited the advantages and disadvantages of using such a cooperation concept. Even though he stated that using economic and business solutions cannot be applied in the case of complex sectors with varied structures [23], he still considered network cooperation to be of greater effectiveness, quality, and end value offered to the customer. 
In the literature, one can also stumble upon network participant typology [24]. The participants (also defined as network actors) take on specific roles, characterizing their functions in the network. One of the roles is the role of an architect, who establishes the initial network and is the creator of mechanisms responsible for its durability, establishing cooperation rules and the roles of specific network participants. Another role is the role of a watchman, who acts as a mediator in case of conflict and misunderstanding. There is also a broker who coordinates the whole enterprise.

Their mutual market relations can vary. Literature [25] names the following:

- Bureaucratic relations, where the linking elements are orders adopted and binding standards and procedures;

- Economic relations, where the linking elements are material and financial transactions;

- Operational relations, where the links between the entities are common activities, collective decision-making, and use of shared resources;

- Cultural relations, where the relationship is based on shared values and a community of opportunities and threats;

- Information relations based on access to, exchange, and sharing of information in the process of establishing the relationship.

Characteristic features of the network are dominating hubs, and their status results from the relations between the remaining network actors. D. Delporte-Vermeiren, P. Vervest, and E. Van Heck [26] indicated that the description of specific network hubs should take place from the point of view of relations that can be noted between its participants (actors). The quantification of these relations is three points of view: a consistency perspective (defined as the number, variety, and density of relations between the hubs), a combination potential perspective (meaning the size and variety of network peaks), and an activation manner perspective (defining the scope of creation of new relations between the network actors) [25]. One must remember, however, that the relations in the networks are often based on the cooperation agreement, but not every actor is directly linked with other network participants. In such a case, we are dealing with indirect links [27].

Entities functioning on a specific market (also, spa markets) can be subject to the networking process. This is made possible thanks to the characteristics of network hubs, that is the ability to establish mutual relations based on knowledge and resource flows, mutual legal and capital independence, the freedom to make a decision to enter or leave the network, activities synergy, possibility to implement both shared and individual objectives, the possibility of modular interaction, the ability to learn from other network actors and to use innovation through teamwork, mutual communication, and complementary character, as well as the ability to enter into risky relations [28]. However, it is worth noting that if the network is created by independent entities, then it can be difficult or even impossible to manage [29]. Therefore, quite often, the process stops at its coordination stage, even though this is also not a widely accepted opinion [30,31]. Irrespective of the adopted terminology, the manner in which the cooperation within the network is carried out and its effectiveness depend on managerial, steering, executive, and coordinating activities [32].

Network coordination is a dynamics of sorts that takes place in interorganizational networks linking various entities, such as public and private entities and natural persons [33]. The literature names four approaches to network governance [34]. These are such issues as good/corporate governance, new public management/market governance, multilevel governance/intergovernmental relations, and network governance. Coordination in an interorganizational network is a complex process, as it depends on the interaction between, quite often, different entities of varied strategic goals that are in a situation where they need to coordinate their activities by taking into account the objectives of other network participants.

P. Perri et al. [35] noticed that the coordination depends on such factors as network symmetry, internal structure, institutional form, adopted and dominating styles of learning, type of business activity, and tasks implemented within the network. The factors threatening network stability are 
the lack of trust, too great a dependence on partners' activities, high complexity, and difficulty of processes implemented together with partners, different levels of absorption abilities concerning competences and skills [33].

An interesting approach to roles within the network is presented by J. Child and D. Faulkener [36], who identify dominated networks with a significant asymmetry of forces (they named them kingdoms) and partners' agreements with equal positions (republics) In the dominated networks, the nature of threats for the cooperation depends on the position occupied by a given entity-central or peripheral. For the latter, the threats are excessive dependency on partners and the risk of loss of independence [37], the risk of unequal use of opportunities offered by networks [38], and the risk of loss of flexibility at the individual level [39]. In the case of peer-to-peer networks, there is a risk of opportunism [38], stagnation in unfavorable relations, hindered forecasting of network development, and lower management control [39].

J. Lichtarski [4] proposed to divide the cooperation relations into two types: A and B. The first-type relations (A) are present when the cooperation is based on mutual complementation of entities-one is able to render a service, and the other expresses a demand for such service and is willing to be its recipient. The second-type relations (B) take place when two entities combine their forces (shared activities and shared resources) to achieve a common goal. In this work, the emphasis is put, in the majority, on the first-type relation (A), while type B is characterized by the use of the identified example of a spa enterprise network.

\subsection{Public Law Networks in Health Resort Enterprise}

It can be noted that on the health resort services market, entities belonging to the private, public, and sometimes also to nongovernmental sectors can be found. In such a case, the network will be characterized by the features of the cooperation network being built, taking into account the public law network. Such networks abstain from traditional separation of the public sphere from the private sphere, focusing its activities on the size of actors in the network and their engagement in order to achieve common goals [40]. On the spa market, one can observe mutual relations between spa enterprises, self-government units (the spa commune representing the local community), as well as suppliers and institutional recipients of spa services and research institutions (in the domain of medicine). The literature analysis indicated that the public law relations, observed within the network, have the following characteristics [41]:

- they are created by independent entities, where at least one is subject to public law;

- their objective is the shared implementation of public interest (it is also possible to generate profit by private entities);

- there are learning processes, based on a mutual adaptation of network participants to one another;

- their participants are independent entities that voluntarily participate in the network;

- relational rent is proof of the effectiveness of the implementation of tasks of public character.

It must be noted that networks established within the spa business are of a mixed character, covering both public and private entities. The motivation of the latter to join the network is to generate greater profits. The public entities, on the other hand, implement, first of all, public interest goals (in this case, objectives of the public health). Therefore, it is important to adopt an approach combining the perspective of private networks (cooperation networks from the point of view of entrepreneurs) with the perspective of public networks.

S. Goldsmith and W.D. Eggers [42] pointed out the features differentiating these approaches. They applied both to the goal and to the importance of relational rent in the carried-out business, as well as to the cooperation effect or the cooperation horizon, the implementation goals and mutual trust. Thus, when it comes to the purpose of the activity, public networks are oriented towards the implementation of public interest, while, in private networks, the individual interest is the dominating one. Relational rent in public networks is the effectiveness measure, while for private 
networks, it is a source of competitive advantage. This also determines the shape of the cooperation effect, which, in public networks, is more difficult to define than in the case of private networks. What unites these two types of networks is the declared importance of trust, which in private networks, more often than not, is limited, as well as the long-term time horizon of activity and objective implementation, where private networks quite often agree to the implementation of short-term objectives. Within the objectives of particular entities belonging to a public network, a low level of compatibility can be observed, as opposed to private networks.

The research carried out by D. Dredge [43] indicates that the network approach, in the case of tourism, is characterized by four advantages. The networks take into account the variety of solutions in tourism, and that these problems are often solved by different communities. The network approach recognizes the fuzzy division of tasks between the private and public sectors and allows them to view tourism as multidimensional space, well-fitted into the rules of shared interest of these two groups. Networks make it possible for various levels of political support for various problems to be present, which, at the same time, differentiate the levels of attention paid to different problems. Network stakeholders can also be participants of other networks, and thus the level of their influence, roles, interactions, and functions in the network can change.

In the process of coordination of networks in tourism, three basic models of conduct can be identified [44]. It can be a network managed by a self-governing unit (e.g., council, government), a network managed by their participants (self-coordinating), or a network managed by a local tourist organization, although, in the case of health resorts, the dominant health insurer can be an informal coordinator.

The Good Governance Advisory Group [45] indicates that good coordination depends, first of all, on the actors of the network and groups associated with the network, their aspirations, and shared values, as well as the decisions made within the responsibility, transparency, participation, communication, knowledge sharing, efficiency, and fairness. The local tourist network coordination effectiveness in achieving goals depends on the effectiveness of structures and institutional processes, relation resources, and available skills [46-48].

In case of sustainable tourism carried out by health resorts, coordination of mutual intrasectoral relations, directed towards the protection of natural resources at the same time as maintaining the right to carry out one's business, is one of the most difficult issues when it comes to determining the shared values of entities belonging to that network.

\section{Materials and Methods}

The analysis of relations between the entities functioning on the spa services market required both theoretical and empirical studies. The theoretical research allowed us to identify the rules of the function of health resort enterprises. It allowed us to identify basic processes of value proposal creation for the customer and value captured by the enterprise. In turn, the empirical research allowed the analysis of the health resort enterprise environment and their mutual business relations. It must, however, be specified that the analysis was not aimed to assess these relations. It served only to show the structure of mutual relations between entities on the spa services market.

The research directed towards the analysis of health resort enterprise business processes and their relations with other entities functioning within this market was carried out in 2018 in 17 of the largest spa enterprises in Poland. The research was carried out by way of indepth interviews with enterprise managers carrying out tourist and therapeutic activities. In the research, a survey questionnaire that characterized the business model structure and market relations was used. The enterprises under analysis were selected from the list of health resort facilities developed and shared by the Ministry of Health by the Republic of Poland. The selection criteria were the largest health resort facilities, having, in total, 33\% share on the health resort market in Poland, carrying out their activity in 95 facilities (spa and spa hospitals), and constituting $36 \%$ of all such facilities in Poland. 
The designed survey questionnaire consisted of 26 items divided by two topics-business models with market relations and health resorts business activity. In the first part of the questionnaire, 18 questions were posed, characterizing the business model structure, considering the CANVAS nine-element model ((1) customers' segment, being the axis of each business model; (2) proposals of values for selected customers' segments; (3) communication channels between the defined elements; (4) relations with customers; (5) revenue streams; (6) key resources, (7) key activities; (8) key partners; (9) cost structure, meaning all the costs related to the execution of the defined business model) and intrasectoral relations. The second pool of questions was concerned with issues associated with the tourist and health resort business activities carried out and market relations resulting from these activities. This made it possible to describe the health resort environment and to visualize the relations occurring in the health resort environment and other entities functioning within this market.

\section{Results and Discussion}

The theoretical research carried out within the literature of the subject and documents governing the rules of providing health resort services and health tourism services in health resort enterprises, as well as empirical studies over the business model of 17 of the largest health tourism enterprises in Poland point to a complex structure of mutual market relations. It is associated mostly with the complexity of the process of providing value for patients. This complexity results from the necessity to reconcile both social goals within the public health initiatives implemented by the spa treatment and economic goals. An important partner of health resort enterprises is usually the national health insurer, which is the key service purchaser. This complexity also results from spa product creation process complexity that can be based on multiple therapeutic raw materials that depend on health resort localization (mineral water, brines, thermal springs, peat, seawater, salt, and therapeutic properties of the climate). The complexity of spa products is enhanced by its mixed service nature, covering both treatment and tourist services, as well as hotels, transport, catering, and even cosmetic services.

\subsection{Using the Business Model and Characteristics of Selected Model Elements}

The empirical studies allowed us to not only to assess the key relations with customers and partners in the environment and recipients' segments, but also the usability of business models associated with the forces of influence of the environment.

The observations made during indepth interviews with health resort enterprise managers indicated that the managers of 5 out of the 17 studied spa enterprises declared that they know and use business models when running their health resort business. However, when the research was deepened in this scope, it turned out that the actual knowledge of business models was scarce and, in general, it referred to their abstract understanding, but without textual or graphic representation, of linked model architecture structures or services that the enterprise was offering. Nonetheless, every third manager taking part in the study had a description concerning particular elements of the business being carried out. In general, the components that underwent modeling were key activities, market segments, communication channels, and customer relations. However, no concise characteristics of business model components were observed; for example, in the form of a detailed description of value proposals for the customer.

The interviews carried out in health resort enterprises proved that, currently, three main segments of recipients of spa services can be identified. Managers of health resort facilities named primarily:

- the segment of institutional recipients (contract);

- the segment of individual recipients (commercial);

- the segment of business recipients.

The first—segment of institutional recipients (also known as contract recipients)—is a group of leading health and social insurers, including National Health Fund (NFZ), Social Insurance Institution (ZUS), Farmers' Social Security Fund (KRUS), and State Fund for Rehabilitation of People with Disabilities 
(PFRON). These insurers sign contracts for health resort services. Beneficiaries of such services are persons insured by these funds, who, once such a need is requested and justified by a general practitioner and then by a balneologist, receive such services in a specified order. A characteristic feature of this market segment is the fact that a direct recipient of health resort services is not the direct payer of the acquired services. It means that the institutional recipient, when acquiring the package of health resort services, does not benefit from it but becomes a holder of such a service.

As it results from the interviews carried out on health resort facilities, from the perspective of health resorts, contracts with insurers are characterized by a low level of profitability due to the adopted contracting criteria. In general, what is decisive is the low price of services, which determines the low attractiveness of stay and limited selection of offered natural therapy treatments. However, the low profitability of contracts does not limit the willingness to win them as, in general, revenues generated thanks to these contracts cover the day-to-day operating costs and ensure stability and possibility of carrying out business activity in other sectors. The source of additional revenue is servicing the second segment of health resort service recipients, being the individual recipients. This is a segment of patients that pay for the stay in the health resort themselves.

The research also indicated that contract and individual recipient groups are key market segments of Polish spa enterprises. Contract patients constitute, on average, $69.9 \% \pm 13.5 \%$ of serviced beneficiaries, $23.2 \% \pm 11.9 \%$ are national individual patients, and $7.5 \% \pm 7.9 \%$ are foreign patients (due to the fact that they pay for their stay themselves, they are classified as individual customers).

Some health resort enterprises generate the greatest profitability from the segment of business recipients. These stays, however, are incidental. This is the most complex segment as it covers stays of varying nature-from corporate team building and recreational trips for employees of a particular facility to industry conferences and special tourist or sports events.

The most important sources of revenue of health resort enterprises are the revenue on hotel activity (accommodation) and treatment services in the form of balneology and physical medicine treatments. Next, categories of revenue cover gastronomy and sale of resources, being at the enterprise's disposal, and then the rental of the premises. The revenues from spa and wellness services and activities of the health resort clinic come next. This structure of revenue sources indicates how important it is for a spa company to maintain lasting relationships with clients in the individual market segments.

Maintaining good relations with loyal customers is one of the basic tasks of every entrepreneur, as it is the level of these relations that quite often decides the profitability and survival of the enterprise on the market. This is also the case for health resorts, although not every patient is treated the same. This results from the fact that contract patients cannot influence the price of offered services (including the service quality) as the direct payer of the benefits is the insurer (who is, in general, guided by the price criterion). Since the return of the contract patient to the facility also does not depend on them, the relations between the personnel and the contract patients are of lesser importance for the service providers in the enterprise than the relations with individual and business customers.

Segments of individual and business customers are the target ones in terms of building positive relations, as this relation should result in the return of the customer to the facility, or at least in positive feedback on the received services via word-of-mouth marketing among potential patients, carried out by the current patients.

The analysis of health resort enterprise activities indicated that the main partners of health resort enterprises are entities, the cooperation with which provides the enterprise with value to capture. The state health and social insurers are of greatest importance, as they make it possible for health resort facilities to make profits on contract implementation. Travel agencies also benefit from individual customers traveling to reach the health resort enterprises.

Just as important as a partner is the spa commune, meaning the self-government administering the health resort, which is responsible for the maintenance of health resort status and caring for the quality of health resort assets (e.g., parks, pump rooms, graduation towers). The commune authorities influence the attractiveness of the health resort as a place of health resort treatment 
and an area of tourist attractions, which is also important for the perception of the health resort offer and the reception of the whole treatment. It is such an important partner that its importance exceeds the importance of key suppliers.

The role of key partners is also played by the suppliers of natural resources, competitors, with whom they cooperate on the basis of competition, outsourcing companies, and advertising agencies. In one facility, it was stated that volunteers are also important partners.

\subsection{The Four-Factor Approach to Design Space Analysis of Business Model}

Using the four-factor approach to design space analysis of A. Osterwalder and Y. Pigneur [3], in the analysis of the health resort enterprise environment, the following forces were subject to assessment: (1) forces influencing the market, (2) forces present in the industry, (3) the most important trends, and (4) general economic forces (Figure 1).

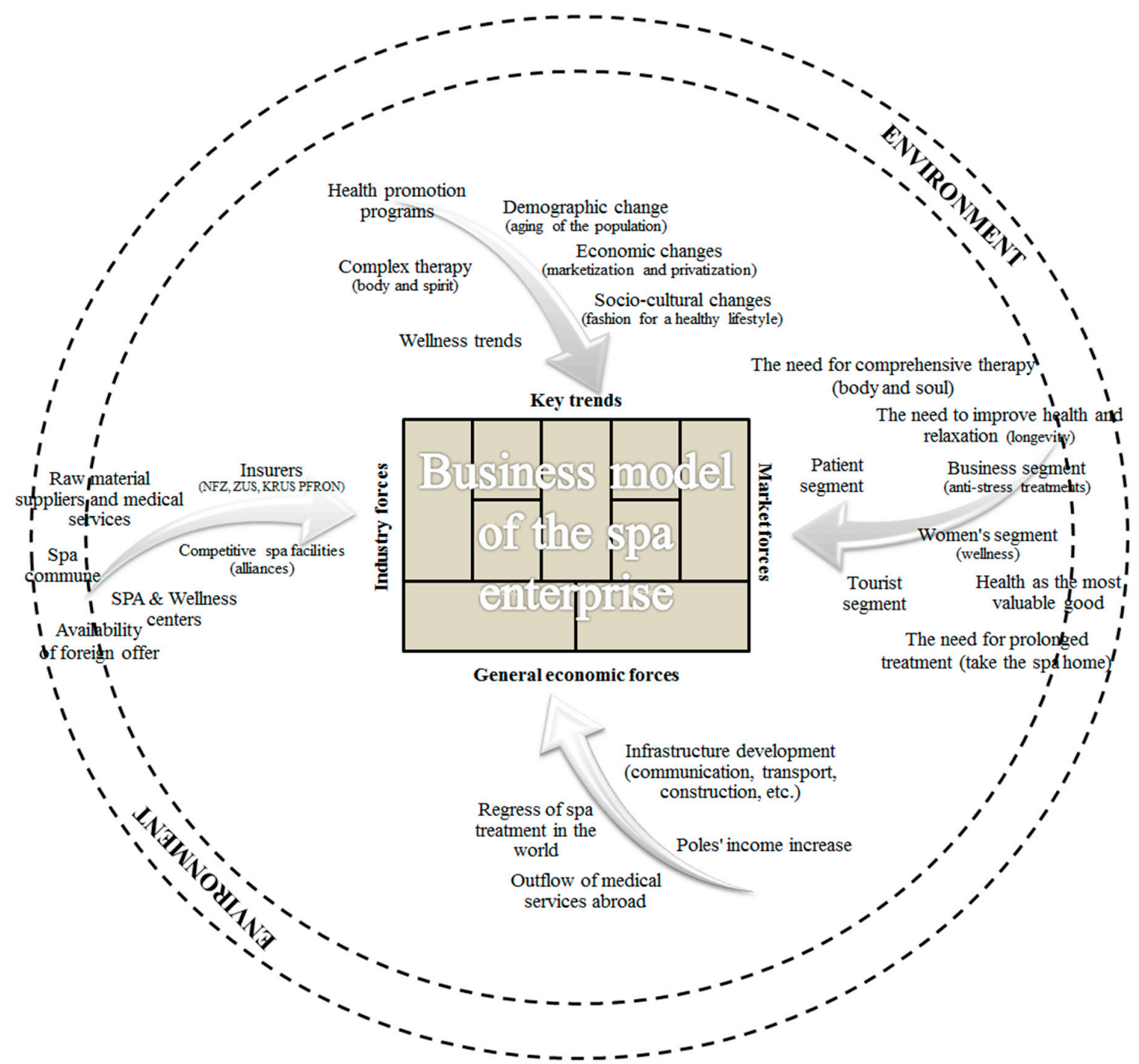

Figure 1. Environmental impact forces on the business model of a spa enterprise. Source: own study.

\subsubsection{Key Trends of Health Resort Market}

The first group of factors of the environment that influences health resort enterprises, which will be subject to characterization, are key market trends, within which the market segments, needs and expectations, market problems, changes costs, and revenue attractiveness were identified. 
New trends that emerged in the health resort market are the factors that have allowed for the rebirth of health resort business activity in the past two decades. Nevertheless, this category is also associated with problematic factors for the whole community.

In this category, several main problems can be named. One of them is demographic changes, especially the aging of society and the associated low fertility rates. It is an extremely crucial factor that influences the offer of Polish spas. Statistics indicate that Poland has one of the lowest fertility rates (1.3) [49]. It also means that the natural generation renewal cannot be observed and that Polish society, or rather European society, is aging at a fast rate. There are a growing number of people of a postworking age, as compared with the number of people of working and preworking ages. These changes also result in greater demand for services associated with the needs requested by the segment of the elderly. These are mostly services associated with health and physical conditions, as well as all forms of spending free time with people of similar characteristics (e.g., seniors, widowers and widows, lonely people).

The influence of the named changes on the market of health resort services is significant as these are seniors who are the main group of recipients of these services, and the forecasted increase in the number of elderly should translate into the increase of the number of beds available in health resorts [50]. It is not, however, obvious, as the example of privatization of multiple health resorts indicates that political activity may squander the development opportunity of a promising market.

Nevertheless, it must be remembered that, along with the aging of Polish society, the change of trends concerning the care of one's body among younger generations must be noted. Therefore, the growth rate for the demand for health services can be greater than the growth of the number of elderly in society.

The second factor is the social and cultural changes that, in the context of public health, take on the characteristics of a healthy lifestyle trend. A manifestation of such attitudes is the more and more frequent rejection of mass products and looking for those created for individual needs. More and more often, it is not the price that is the basic criterion when it comes to making a decision to buy therapeutic goods and services, but the effectiveness and durability of the therapy effect. The increase in society revenues has made it possible to increase the standard of living of the poorest people. Along with growing revenues, the demand for services meeting higher-order needs also increases. The therapeutic treatment, although it refers to human health, is not a so-called bare necessity. It is a complementation of hospitalization, therapy carried out by general practitioner or specialist, and sometimes it has an entirely prophylactic character, as a manner of health prevention.

The healthy lifestyle trend is also manifested in the growing popularity of sports facilities and initiatives on the side of local self-government to build open-air gyms financed by way of participatory budgets. What can also be observed is the growing number of spa and wellness centers (especially in health resorts), as well as shops with so-called organic food. More and more often, consumers are choosing more expensive products of higher quality that better meet the demand of society.

Another factor is economic changes linked with the marketization of health resort business activity and changes in ownership. The reform of state health care facilities, including health resort facilities, carried out in Poland in the 1990s, resulted in a radical change in the situation of these entities. State health resort enterprises, so far fully financed from the state budget, were faced with the necessity of independent fund-raising to finance their activity. The health resort services were still financed from social funds but were acquired on the basis of tenders, where the criterion was the lowest price. This resulted in a decrease in the quality of health resort services (the quality of accommodation, catering) and, at the same time, limited the availability of treatment financed by the state. This phenomenon resulted in a new segment of recipients of health resort services, being patients agreeing to undergo fully-paid therapy.

The ownership changes mentioned before, which took place in the years 2005-2016 in the health resort sector, resulted in the almost complete resale of state health resort companies. Part of the sold enterprises 
became the property of other state companies, becoming their additional activity. As a consequence of the marketization of health resort enterprises, the willingness to implement social goals decreased for economic goals, as currently in health resort facilities, it is more profitable to accommodate patients who pay for their stay themselves than patients referred for therapy by the insurers.

Another factor that influences the business relations model in health resorts is health programs financed by the local government units and government, as well as government policy associated with the preventive medicine of Poles. All activities promoting a healthy lifestyle can raise awareness on preventive medicine and reduce the possibility of premature death. Contact with nature in a natural environment and staying away from work and everyday life is one of the best ways to combat modern-age diseases.

One of the most important influencing factors is the observed trends of biological and spiritual renewal (spa and wellness). More and more often, offering therapy that combines a stay at a spa has a specific mental impact that can be observed. These are services covering complex activities in the scope of individual needs of the patient, not only in the sphere of treatment but also in the sphere of relaxation directed towards psycho-physical balance. Rest in a place that fosters relaxation is complemented with cosmetic services, rehabilitation, and relaxation classes (especially relaxation techniques having their sources in Eastern cultures).

The influence of these trends on the model of mutual relations between the entities of this sector can be linked with the necessity to propose additional offers in health resort enterprises in the scope of services improving the mental state of the patients (spiritual exercises, relaxation techniques, and cosmetic services). Even though these are not services directly linked with health resort treatment, it is perhaps worth considering the so-called hybrid therapies complementing traditional health resort therapy, with services regulating psychological and physical balance.

\subsubsection{Forces of the Health Resort Industry}

In the case of forces of the health resort industry, an important element influencing the relations in health resort enterprises is the influence of state health and social insurers, meaning the National Health Fund (NFZ), the Social Insurance Institution (ZUS), the Farmers' Social Security Fund (KRUS), and the State Fund for Rehabilitation of People with Disabilities (PFRON). The strength of their influence results from their role as an administrator of funds, having their source in the state budget. These are, in general, the main recipients of health resort services in Polish health resorts. They play the role of a payer for the health resort services on behalf of the patient, as the contributions paid by the patient to the state budget are administered by the insurers who, when the need to use the health resort therapy arises, cover the costs of the patient's stay in part or in whole.

It can, therefore, be stated that even though state insurers are not the direct beneficiaries of health resort services, often they act as a payer and contractor, ordering the benefits by being in direct contact with health resort enterprises. It is worth emphasizing that the maintenance of traditional balneology and rehabilitation medicine is possible mainly thanks to the contracts signed with state insurers, as this is still the main source of financing of natural therapy treatments and stays in spas and spa hospitals.

Another group of key contractors of health resort enterprises is the suppliers of natural medical raw materials and the medical employees responsible for therapy at the facility. It must be stated that both the suppliers and medical services can form a part of the health resort facility, yet in the majority of cases, these are separate economic entities, with whom constant cooperation is concluded. These entities, for example, deliver peat, brines, and mineral waters or provide specific therapeutic services (for example, physical exercises in the pool). As such, they play the role of one of the key partners of the health resort enterprise.

Another factor that influences the industry forces is the spa commune and its administration. This results from the fact that, in Polish law, a health resort is a territorial area being administered by local authorities. This is the spa commune that submits the request to the state to be granted the status of a health resort, as well as creating and financing the health resort survey that is the basis 
of the request to be granted such a status. The spa commune is also responsible for determining and supervising the health resort spheres, taking care of health resort assets (health resort park, graduation towers, pump rooms), and collecting local tax from the guests coming to the health resort (tourists and patients). The spa commune administration is responsible for many control and coordination obligations, associated with the implementation of the provisions of the Act of 28 July 2005, on health resort treatment, health resorts and areas of health resort protection, and spa communes (Journal of Laws 2005, no. 167, item 1399 [6]).

Influence on the health resort sector is also associated with the presence of health resort competitors. These are not only entities providing substitution services, but also direct competition in the industry, meaning other health resort facilities functioning in the same or neighboring health resort.

Even though the approach to the described model is universal-applying, in general, to health resort enterprises and not to a specific enterprise-one must also take into account this competitive surrounding. The entities rendering the same or similar services in the same or neighboring area can undertake varied forms of cooperation (cooperation, competition) or focus on their own specialization and attempt to differentiate themself from the competition.

In some health resorts, it can be noticed that one health resort or a complex of health resorts with one management dominates, and, in some cases, the market is divided between scarce entities of a similar influence. There are also such health resorts areas where only one health resort is present (that does not have a direct competition). The influence of the competition on the business model of a specific entity in each of these cases will be different and must be analyzed separately.

One of the substitution competitors is facilities and centers offering spa and wellness services, meaning services within the health and wellness-oriented stays. These facilities aim to integrate the physical, psychological, and spiritual spheres of a person using these services in order to achieve a balance in the natural and social environments [51].

Due to the implemented business activity profile, these facilities do not use health resort therapy (balneology and rehabilitation) and more often reach for unconventional therapeutic methods, in general, complementing the health resort offer.

A direct competitor of the health resort facilities is also the tourist facilities located in the health resort as they render similar services as the health resort enterprises. They do not have a natural therapy base, but they use the available therapy services with the cooperation of the health resort.

\subsubsection{Forces of the Health Resort Market}

The health resort market, being a part of a healthcare market, has varied forces of influence on the business model associated with segments of recipients and the needs voiced by them. The health resort market is based on the need to restore or maintain the health of the patients, but its main parts are also nonmedical services rendered for the guests staying in the health resorts for various specific purposes. These services benefit the health and recreational (tourist) objectives, as well those associated with the specific specialization of the health resort product.

One of the needs voiced in health resorts and spa and wellness facilities is the need for hybrid therapy (covering with its scope the body and soul). This therapy has already been mentioned when discussing the present therapeutic trends. It is a form of health resort product that combines therapy influencing the body with treatments referring to the mental and spiritual states of the person visiting the facility. Therapeutic treatments concerning the body are mostly rehabilitation and balneology. Treatments concerning the mental and spiritual states can cover many forms of more or less intensive influence (e.g., visits to salt grottos, consultation or psychotherapy, meditation exercises, relaxation techniques, and prayers).

Some needs of the patients result from their desire to live their lives in good psycho-physical conditions. Thus, their needs are not based on the current situation, but rather take into consideration the distant future. Therefore, they have a preventative character, with reference to old age. Other needs result from the desire to extend the health resort therapy at home by continuing some therapeutic 
methods. It is strictly associated with another task of the health resort therapy, where, apart from treatments, they should provide health education.

All the mentioned human needs are supported by the philosophy that states that human health is the most precious physical good that a man can have and that it is not constant. Therefore, it requires care in order to be maintained as long as possible. Along with the needs that emerge on the health resort market, it is also worth attempting to identify basic market segments. Apart from the already mentioned division of recipients (institutional, individual, and business), other divisions can also be identified. They most often result from the age criteria, dividing recipients of services into seniors $(65+)$ and other patients (younger than 65 years old). Still, this division, although necessary, is also insufficient, as, within the identified age groups, subgroups with varied characteristics can be named. Taking into account the changes in the offer directed towards younger market segments, the age criterion should be made more specific. It is, therefore, proposed to distinguish the recipients of health resort services, also taking into account the typology criterion, which is associated, for example, with the manner of how the treatment is financed, what the objective of the stay is, and if the patient needs to make use of specialist programs.

The first criterion of segmentation should be the age of patients (for example, $65+$ ) as, in the times of aging society, this group of recipients will significantly increase the market potential. However, when it comes to the remaining part of the society (up to the age of 65), it is worth identifying additional segments of specific needs. One such market segment is, undoubtedly, the segment of children and youth (up to the age of 18), for whom special offers and even health resorts' profiles are prepared (an example of a children's health resort is Rabka Zdrój). Another age segment consists of patients over 40 years old, who, during and after their intensive career or as a result of everyday hardships, feel the need to rest in a place where one can regenerate.

One of the basic methods of dividing patients, apart from age, is the already described division into individual patients (who pay for the stay themselves) and contract patients (institutional ones), meaning beneficiaries of health resort treatments paid by the insurer. A subgroup of patients that pay for their stay themselves, although less numerous than the group of contract patients, is the most profitable group. This group encompasses foreign patients. What is characteristic for this group of recipients is the fact that they are the decision-makers when it comes to the place, time, and duration of the treatment. This is not the case for the contract subgroup, which goes to the place of treatment indicated by the insurer and balneologist for a specific period (21 days) and at the time dictated by the insurer (in general, taking into account the queue managed by the insurer).

Another division is focused on the segment of tourists, who are not accommodated in the spas and spa hospitals, but elsewhere (guest houses, hotels, family), but they use the treatments offered by the natural therapy facility under the supervision of balneologists. Such a stay can cover both the treatments financed by the health insurer (within outpatient treatment), as well as treatments financed independently by their beneficiary. This group is neither subject to the health resort regime nor to medical and nurses' supervision in the place of accommodation.

It is worth mentioning that there are two other main segments of recipients. First is the segment of women using beauty and relaxation treatments. In this case, the health resort therapy serves mostly treatments of cosmetic and relaxation purposes and, by the way, also health purposes. There is no inconsistency with the objective of health resort function, as many treatments offered by natural therapy facilities are also treatments not only with health properties but also influencing body care (pearl baths, brine baths).

Another group of recipients is the segment concerning the needs of businessmen, both in the aspect of entrepreneurs, managers, as well as authorities, who, burdened with stress, feel the need for antistress therapy. In this segment, employees can also be found, where, as a reward for their work, they are sent to relax in a health resort.

One can name many other segments of the health resort market of lesser importance and influence on the business model. These can be individual or group recipients for whom a special offer 
was prepared, for example, a stay for mental support groups within health resort therapy (for war veterans, pregnant women, mothers with children) or training camps for biological renewal.

\subsubsection{General Economic Forces}

The influence of the forces discussed so far (industry, market, and trends) can be complemented with general economic influence concerning the remaining aspects of the environment. In this case, factors and phenomena that can influence the business model structure were taken into account. One such factor is undoubtedly the HR situation in healthcare and, especially, the lack of specialist doctors [52]. The lack of necessary medical staff can decrease the quality of services and, in some cases, even limit the ability to render health resort services. In a spa business at a health resort, it is necessary to have specialization in balneology and rehabilitation.

In addition, worth noticing is the phenomenon of health resort treatment regress globally. There is a limited number of state health care systems that consider health resort treatment to be an integral part of it (as is the case in Poland [6]). In the majority of countries, traditional balneology treatments are often an element complementing the stay in spa cities and facilities and even on mobile health resorts (ships) [53]. This is not the case in Europe, where traditional health resort treatment, based on minerals and health properties of the climate, is still developing [54], expanding the scope of benefits.

An important factor is the development of health resort infrastructure and nonhealth resort infrastructure (communication, transport, buildings). It concerns the availability of health resort services, which are specific services offered only in health resorts, that need to be accessed individually to make use of the therapy. This is a factor that has both positive and negative influences on the health resorts: the development of infrastructure positively influences the business, but it is not always beneficial for the natural environment. At the same time, quite often, this factor becomes an obstacle associated with the excess of infrastructure and excess of critical levels of capacity and tourist absorption of the spa area, after which health resort degradation and the degradation of tourist and health functions take place [55].

The increase of revenues, especially in the group of the poorest, opens new possibilities for the health resorts. These are health resorts that are often a place of relaxation and treatment for those with the lowest income (retirement pension and pension holders, unemployed), as they can make use of accommodation that is financed from public funds. It is also quite often a challenge, as this segment is often not aware of the possibility of making use of the, so far, unattainable health benefits and holiday services. Additional revenues also mean the extension of the scope and number of communication channels with potential patients (for example, the Internet). It undoubtedly has an influence on business processes, especially in the scope of segments, channels, and streams of revenue.

The last factor of influence on health resort activity is the law that governs the functioning of health resorts and, in general, the functioning of tourist enterprises and areas. This is, however, an issue that varies depending on a country.

The performed analysis of health resort enterprises and their environment has made it possible to characterize the mechanisms and business relations concerning the health resort sector. The complementation of the analyses is the graphic model of business relations in the health resort environment. In the scope of relations of the first type, where the cooperation model is present, being about entities that complement one another, the business relations model was presented in the form developed by the Board of Innovation [16]. It can be seen in Figure 2. 


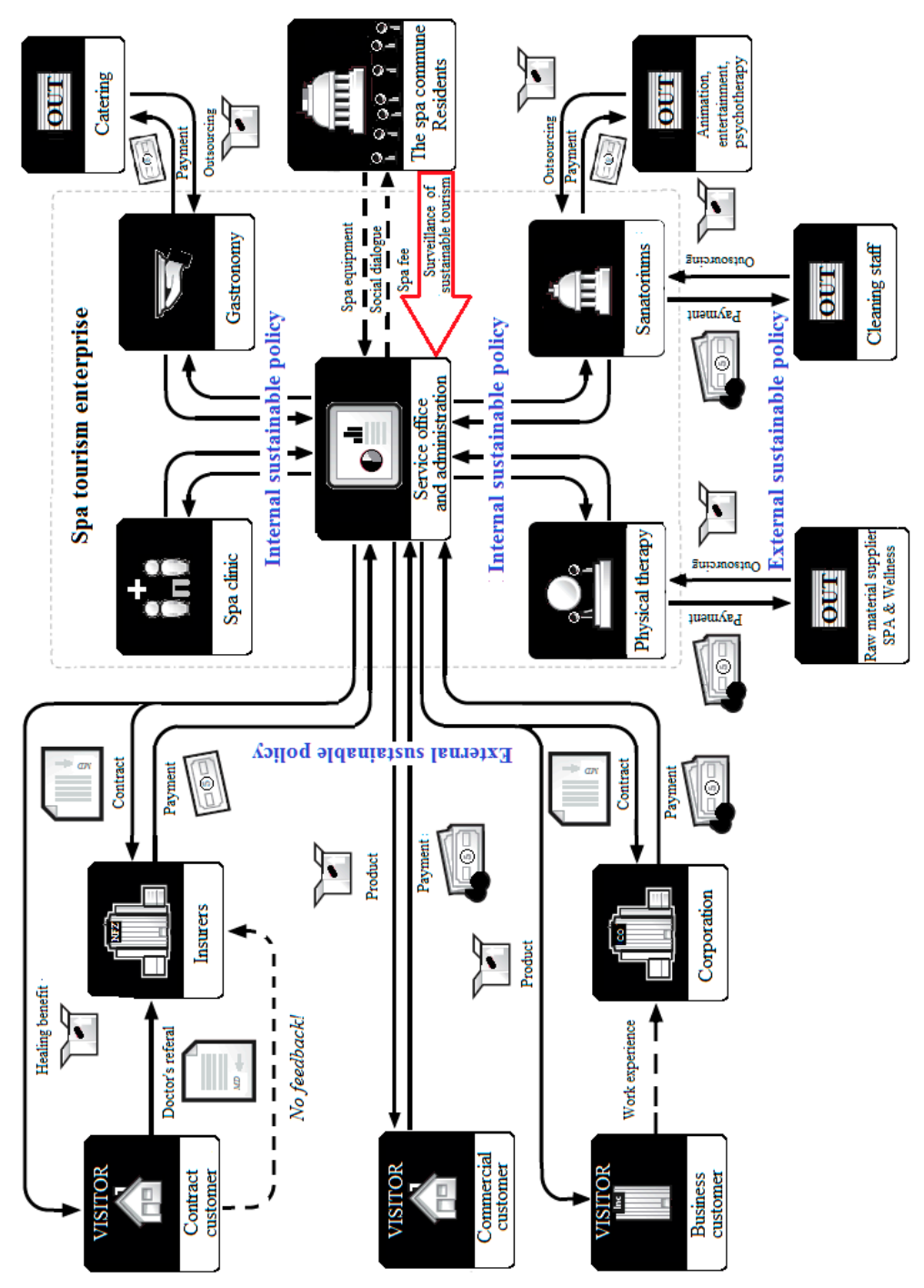

Figure 2. Model of health resort enterprise relations in its environment. Source: own study.

The relations shown in Figure 2 are based on the business objectives of particular entities, but it is also worth indicating their links with the objectives of sustainable tourism. In modern times, it becomes necessary to develop sustainable policy in the scope of implementation of sustainable development rules. In the case of health resorts, these rules should be defined separately for internal relations of business model elements and separately for external relations focusing on local cooperation. The internal sustainable policy should take into account as criteria proposed by the Global Sustainable Tourism Council (GSTC) [5] in the scope of proecological behaviors, in particular, concerning economic use of natural resources (both used for health resort treatment and for other purposes) and reduction of pollution (gas emission, transport, water, and electric energy), as well as combating the results of overtourism, overpopulation, and excess infrastructure. The internal sustainable policy should also cover the education of behaviors that protect the natural environment and local culture, directed towards the recipients of health resort services. It is one of the missions of socioeconomic entities, carried out to increase the responsibility for the health resort and cultural resources of the commune being visited, and for the place where the patient functions every day.

The external sustainable policy should be based on providing information on the implemented practices within the internal sustainable policy, encouraging people to undertake and maintain proecological behaviors among suppliers and contractors, and even among competitors. 
During field research, carried out in Polish health resorts, what was also identified were the interorganizational networks of the second type, where the entities combine forces within a joint effort and resource sharing in order to achieve a common goal. Several such networks were identified among Polish health resort enterprises. The greatest network is composed of several health resorts named Polska Grupa Uzdrowisk (PGU) (Poland, Wrocław, 2-8 W. Sikorskiego Street) [56]. It is a company established on the basis of business relations of five health resort enterprises: Uzdrowisko Cieplice Grupa PGU, Uzdrowisko Połczyn Grupa PGU, Uzdrowisko Świeradów-Czerniawa Grupa PGU, Uzdrowiska Kłodzkie Grupa PGU, and Interferie Medical Spa. The owner of this network is KGHM Polska Miedź I Fundusz Inwestycyjny Zamknięty Aktywów Niepublicznych (First Closed Investment Fund of Non-Public Assets) (Poland, Lublin, 48 M. Skodowskiej-Curie Street), which focuses its activity on protecting health in health resorts and on promoting leisure activity. According to the information of the owner of KGHM TFI, the long-term strategy of the development of PGU [56], adopted at the beginning of 2015, resulted in an increase in the financial results of health resort companies belonging to PGU. This is due to the adopted investment policy that assumes a constant increase of hotel infrastructure standard and the standard of treatment equipment, as well as due to the development policy associated with extending the institutional contracts and effective winning of customers from the country and abroad, who pay for their stays themselves.

The interorganizational network of this type is based on slightly different relations than the ones present in Figure 2. Therefore, it will be a subject for further studies. This is also an area that the author considers to be a base for further analyses, this time of an interorganizational nature, based on the rules of competition of competitors functioning in separate territories.

\section{Summary}

Research conducted with the managers of the largest spa tourism facilities in Poland has shown that business relationships are mainly built there with three groups of entities. The first group consists of clients from three market segments with different impacts on corporate income. These relationships depend on whether the recipient is also a payer of spa services or only the beneficiary of services financed by the insurer. Secondly, relationships are built with the closest contractors (e.g., suppliers of medicinal raw materials, centers that perform spa treatments, or catering outlets). The third entity to build relationships with is local government units that affect the perception of the spa area by tourists; in crisis situations, they become the main disposer of spa treatment facilities.

It is worth noting that the environment of health resorts is characterized by multiple factors influencing the structural elements of their business models and relations taking place in these environments. It is, in particular, linked with the presented social influences in the form of changing expectations of recipients of health resort services, the trend of healthy lifestyles, relaxation, and destressing, as well as the influence of competition and insurers and even changes taking place in the economy. Each of the discussed factors influences enterprise activity, even though the force of influence may differ. The analysis of mutual relations of health resort enterprises and the interdependent entities makes it possible to order the processes and to modify the mutual relations in a situation when it is necessary to adapt to changes in the environment. It can, therefore, increase the ability of the enterprise to benefit from changes taking place in the environment and to flexibly introduce changes to its function in relation to the environment.

The considerations concerning the forces of influence of the health resort environment and elements comprising health resort enterprise business models are characteristic of the business relations model on this market. An important issue resulting from the business relations presented here is the separation of sustainable policy that covers the introduction and maintenance of proecological and procultural activities in the health resort area. The author hopes that the health resort enterprises will adopt the sustainable business and natural environment policies for mutual benefits and that they will encourage such practices among their contractors and recipients. 
It should also be admitted that due to the complexity of the research problem, the weakness of the research is the lack of possibility to develop precise guidelines for spa companies. Each enterprise should take into account individual assumptions for modeling relations with the environment and indicate which business relations are key from its own perspective. Individual criteria for assessing market relations will be an important element of the strategy of each enterprise.

It is worth considering what these criteria will be. Economic perturbations and the crisis associated with the spread of the SARS-CoV-2 virus at the beginning of 2020 [57-59] have shown how important relationships between cooperating companies in the same market are. Entrepreneurs have recognized that the sustainability of mutual relations may be the only chance to survive the global crisis, especially in tourism.

This view of the research problem undertaken in the article suggests that intrasectoral relationships should also be based on building mutual trust, especially in crisis situations. The business models of spa companies should develop relationships with clients and entities with whom they cooperate on the market, but also with the state, through cooperation with local government units. An eloquent example is the situation during the COVID-19 pandemic, when all Polish spa tourism enterprises became a reserved resource in the event of overcrowding of hospitals. Despite the dismissal of the threat of overcrowding in hospitals where coronavirus patients were treated, places in Polish spa facilities were used for health prevention and quarantined persons. It seems that such practices in the future may be a good solution for maintaining health safety and should be a topic more often undertaken in future research.

Funding: This research received funding from the National Science Center in Poland.

Acknowledgments: This paper was published as part of the research project "A business model for health resort enterprises" No. 2017/25/B/HS4/00301, supervised and financed by the National Science Center in Poland and as part of statutory research ROZ 1: 13/010/BK_20/0042 at the Silesian University of Technology, Faculty of Organization and Management.

Conflicts of Interest: The author declares no conflict of interest. The funders had no role in the design of the study; in the collection, analyses, or interpretation of data; in the writing of the manuscript, or in the decision to publish the results.

\section{References}

1. Butler, R.W.; Szromek, A.R. Incorporating the Value Proposition for Society with Business Models of Health Tourism Enterprises. Sustainability 2019, 11, 6711. [CrossRef]

2. Khair, Q.; Saeed, M.M. Different ways of synergistic effects of human resource management (HRM) practices on organizational performance: A method of $2+2=5$. Afr. J. Bus. Manag. 2011, 5, 8610-8616.

3. Osterwalder, A.; Pigneur, Y. Business Model Generation: A Handbook for Visionaries, Game Changers, and Challengers, Paperback; John Wiley and Sons: Hoboken, NJ, USA, 2010; pp. 204-214.

4. Lichtarski, J. Współpraca przedsiębiorstwa z innymi podmiotami gospodarczymi. In Podstawy Nauki o Przedsiębiorstwie; Lichtarski, J., Ed.; AE we Wrocławiu: Wrocław, Poland, 2007; pp. 420-421.

5. GSTC, Global Sustainable Tourism Cuncil. GSTC Criteria for Hotels. GSTC Criteria for Tour Operators. GSTC Criteria for Destinations. 2019. Available online: http://www.gstcouncil.org/gstc-criteria/ (accessed on 1 August 2019).

6. Journal of Laws, The Act of 28 July 2005 on spa treatment, spas and spa protection areas, and on spa municipalities (Dz.U. 2005 r. Nr 167, poz. 1399).

7. Magretta, J. Why Business Models Matter? Harvard Business Review, 1 May 2002; 86-92.

8. Battistella, C.; Toni, A.; Zan, G.; Pessot, E. Cultivating business model agility through focused capabilities: Amultiple case study. J. Bus. Res. 2017, 73, 65-82. [CrossRef]

9. Wit, B. Ekologistyka w Systemie Zarzadzania Odpadami Niebezpiecznymi; Towarzystwo Naukowe Organizacji i Kierowania. Stowarzyszenie Wyższej Użyteczności Dom Organizatora: Toruń, Poland, 2016; p. 138.

10. Oskam, I.; Bossink, B.; Man, A.P. The interaction between network ties and business modeling: Case studies of sustainability-oriented innovations. J. Clean. Prod. 2018, 177, 555-566. [CrossRef] 
11. Tong, X.; Tao, D.; Lifset, R. Varieties of business models for post-consumer recycling in China. J. Clean. Prod. 2018, 170, 665-673. [CrossRef]

12. Rossignoli, F.; Lionzo, A. Network impact on business models for sustainability: Case study in the energy sector. J. Clean. Prod. 2018, 182, 694-704. [CrossRef]

13. Teece, D. Business models and dynamic capabilities. Long Range Plan. 2017, 51, 40-49. [CrossRef]

14. Foss, N.J.; Saebi, T. Business models and business model innovation: Between wicked and paradigmatic problems. Long Range Plan. 2018, 51, 9-21. [CrossRef]

15. Prendeville, S.; Bocken, N. Sustainable Business Models through Service Design. Procedia Manuf. 2017, 8, 292-299. [CrossRef]

16. Board of Innovation, THE INNOVATION MATRIX; 15 Companies You Should Copy. Business Models Visualized by @boardofinno; 50+ Business Models You Should Copy Today, Board of Innovation. Available online: www.boardofinnovation.com (accessed on 19 October 2018).

17. Obłój, K. Strategia Organizacji; PWE: Warszawa, Poland, 2001; p. 12.

18. Nogalski, B. Modele biznesu jako narzędzia reorientacji strategicznej przedsiębiorstw. Master Bus. Adm. 2009, 17, 3-14.

19. Porter, M. Strategia konkurencji. Metody analizy sektorów i konkurentów; PWE: Warszawa, Poland, 2000; p. 23.

20. Penc, J. Decyzje i Zmiany w Organizacji; Difin: Warszawa, Poland, 2007; p. 72.

21. Håkansson, H.; Ford, D. How should companies interact in business networks? J. Bus. Res. 2002, 55, $133-139$. [CrossRef]

22. Hall, C.M. Rethinking collaboration and partnership: A public policy perspective. J. Sustain. Tour. 1999, 7, 274-289. [CrossRef]

23. Hall, C.M.; Page, S.J. Progress in tourism management: From the geography of tourism to geographies of tourism-A review. Tour. Manag. 2009, 30, 3-16. [CrossRef]

24. Stabryłwa, A.; Wawak, S. Metody Badania i Modele Rozwoju Organizacji, Encyklopedia Zarzadzania; Mfiles.pl: Kraków, Poland, 2012.

25. Strategor. Zarzadzanie Firma. Strategie, Struktury, Decyzje, Tożsamość; PWE: Warszawa, Poland, 1995; p. 392.

26. Delporte-Vermeiren, D.; Vervest, P.; Van Heck, E. In search of margin for business networks: The European patent o_ce. Eur. Manag. J. 2004, 22, 167-182. [CrossRef]

27. Gomes-Cassers, B. Group versus group: How alliance networks compete. Harv. Bus. Rev. 1994, 72, 62-66.

28. Czakon, W. Dynamika Więzi Międzyorganizacyjnych Przedsiębiorstwa; Uniwersytet Ekonomiczny w Katowicach: Katowice, Poland, 2007; p. 163.

29. Parvinen, P.; Lukkari, P. Changing Healthcare Networks-Orchestrating Needed but Impossible? 2007. Available online: www.impgroup.org/uploads/papers/5922.pdf (accessed on 20 April 2017).

30. Bryant, J. The Six Dilemmas of Collaboration. Interorganisational Relationships as Drama; John Wiley \& Sons: West Sussex, UK, 2003; pp. 187-207.

31. Möller, K.; Svahn, S. Managing Strategic Nets: A Capability Perspective. Mark. Theory 2003, 3, $201-226$. [CrossRef]

32. Kale, P.; Dyer, J.H.; Singh, H. Alliance capability, stock market response and long-term alliance success: The role of the alliance function. Strat. Manag. J. 2002, 23, 747-767. [CrossRef]

33. Powell, W.W.; Koput, K.W.; Smith-Doerr, L. Interorganizational collaboration and the locus of innovation: Networks of learning in biotechnology. Adm. Sci. Q. 1996, 41, 116-145. [CrossRef]

34. Klijn, E.H. Governance and Governance Networks in Europe. An Assessment of Ten Years of Research on the Theme. Public Manag. Rev. 2008, 10, 505-525. [CrossRef]

35. Perri, P.; Goodwin, N.; Peck, E.; Freeman, T. Managing Networks of Twenty-First Century Organizations; Palgrave Macmillan: Hampshire, UK, 2006; pp. 31-32.

36. Child, J.; Faulkner, D. Strategies of Co-operation. Managing Alliances, Networks and Joint Venture; Oxford University Press: Oxford, UK, 1998; p. 120.

37. Dryl, T. Organizacja sieciowa. In Koncepcje Zarządzania. Podręcznik Akademicki; Czerska, M., Szpitter, A., Eds.; C.H. Beck: Warszawa, Poland, 2010; p. 256.

38. Stańczyk-Hugiet, E.; Sus, A. Konsekwencje przynależności do sieci. In Sieci Międzyorganizacyjne. Wspótczesne Wyzwanie dla Teorii i Praktyki Zarzadzania; Niemczyk, J., Stańczyk-Hugiet, E., Jasiński, B., Eds.; C.H. Beck: Warszawa, Poland, 2012; pp. 92-94. 
39. Sroka, W. Korzyści i zagrożenia uczestnictwa w sieci aliansów-Analiza porównawcza. Przegląd Organ. 2010, 1, 29-30. [CrossRef]

40. Kjaer, A.M. Rzadzenie; Wyd. Sic!: Warszawa, Poland, 2007; p. 13.

41. Niemczyk, J.; Stańczyk-Hugiet, E.; Jasiński, B. (Eds.) Sieci Międzyorganizacyjne, Wspótczesne Wyzwanie dla Teorii i Praktyki Zarzadzania; C.H. Beck: Warszawa, Poland, 2012; p. 181.

42. Goldsmith, S.; Eggers, W.D. Governing by Network; Brooking Institution Press: Washington, DC, USA, 2004.

43. Dredge, D. Policy networks and the local organization of tourism. Tour. Manag. 2006, 27, 269-280. [CrossRef]

44. Dredge, D. Local tourism governance: A comparison of three network approaches. J. Sustain. Tour. 2010, 18, 7-28.

45. Good Governance Advisory Group. Good Governance Guide: The Principles of Good Government within Local Government; The Municipal Association of Victoria: Melbourne, Australia, 2004.

46. Bell, S. "Appropriate" policy knowledge, and institutional and governance implications. Aust. J. Public Adm. 2004, 63, 22-28. [CrossRef]

47. Halley, P. Transforming governance: Challenges of institutional adaptation and a new politics of space. Eur. Plan. J. 2006, 14, 299-320. [CrossRef]

48. White, L. Effective governance through complexity thinking and management science. Syst. Res. Behav. Sci. 2001, 18, 241-257. [CrossRef]

49. Szromek, A.R. Changes in the management model of health care institutions in health resorts in the context of social and economic changes in the years 1989-2018. Health Prim. Care 2018, 2. [CrossRef]

50. Szromek, A.R. Działalność Turystyczno-Lecznicza Zakładów Lecznictwa Uzdrowiskowego. Transformacja Działalności Przedsiębiorstw Uzdrowiskowych w Latach 1989-2010; Proksenia: Kraków, Poland, 2011; pp. 69-83.

51. Myers, J.; Sweeney, T.; Witmer, J. The Wheel of Wellness counseling for wellness: A holistic model for treatment planning. J. Couns. Dev. 2000, 78, 251-266. [CrossRef]

52. Krajewski-Siuda, K.; Szromek, A.R.; Romaniuk, P. Emigration preferences and plans among medical students in Poland. Hum. Resour. Health Springer 2011, 10, 8-12. [CrossRef]

53. Spivack, S.E. Health spa development in the US: A burgeoning component of sport tourism. J. Vacat. Mark. 1998, 4, 65-77. [CrossRef]

54. Somkeatkun, W.; Wongsurawat, W. Perceptions of the Spa Industry: An Importance Performance Analysis. J. Qual. Assur. Hosp. Tour. 2017, 18, 416-436. [CrossRef]

55. Butler, R.W. The Concept of the Tourism Area Cycle Evolution: Implications for Management of Resources. Can. Geogr. 1980, 24, 5-12. [CrossRef]

56. Polska Grupa Uzdrowisk. Polska Grupa Uzdrowisk w Trendzie Wzrostowym. Available online: http: //tfi.kghm.pl/polska-grupa-uzdrowisk-w-trendzie-wzrostowym/ (accessed on 16 July 2018).

57. Sigala, M. Tourism and COVID-19: Impacts and implications for advancing and resetting industry and research. J. Bus. Res. 2020. [CrossRef]

58. Naeen, M.; Che Suraya, Z. Religious tourism and mass religious gatherings-The potential link in the spread of COVID-19. Current perspective and future implications. Travel Med. Infect. Dis. 2020, 101786. [CrossRef]

59. Zenker, S.; Kock, F. The coronavirus pandemic-A critical discussion of a tourism research agenda. Tour. Manag. 2020, 81, 104164. [CrossRef] [PubMed]

(C) 2020 by the author. Licensee MDPI, Basel, Switzerland. This article is an open access article distributed under the terms and conditions of the Creative Commons Attribution (CC BY) license (http://creativecommons.org/licenses/by/4.0/). 